\title{
3D printing in Healthcare
}

John Hornick is a partner based in the Washington, DC, USA, headquarters of the Finnegan IP law firm, one of the largest IP firms in the world. Based on his more than 30 years of experience, Hornick counsels clients on virtually every aspect of IP law. He founded Finnegan's 3D Printing Working Group and advises and educates clients about 3D printing and the IP issues of this rapidly developing and potentially disruptive technology, and how it may affect their businesses. He is the author of the award-winning book, 3D Printing Will Rock the World. The only IP attorney selected by the National Academies to participate in the US Comptroller General Forum on Additive Manufacturing (which was the basis of a report to the US Congress), and a juror for the International Additive Manufacturing Award, Hornick has been widely published and frequently speaks on 3D printing and its potential effects on IP law and the world.

First draft submitted: 22 March 2016; Accepted for publication: 10 April 2016; Published online: 12 August 2016

Healthcare has a broad range of $3 \mathrm{D}$ printing developments that seems amazing today but that will probably seem commonplace in a few years, as even more impressive advances eclipse them. Walter Reed Army Medical Center has 3D printed titanium cranial implants [1], and replaced a woman's jaw with a 3D printed prosthetic [1]. In 2013 doctors replaced $75 \%$ of a man's skull with a 3D printed implant made by a company called Oxford Performance Materials [2]. In the UK, doctors replaced half of the pelvis in a man with a rare type of cancer [3]. Tens of thousands of replacement hip cups have been printed and implanted into patients [4].

Other 3D printing developments in health care include noses [5], skin [6], customized coverings for artificial limbs [1], cosmetic ears [7,8] and bionic ears [9]. About $95 \%$ of all hearing aid shells are $3 \mathrm{D}$ printed $[1,10]$. The molds for about 17 million teeth aligners are $3 \mathrm{D}$ printed every year $[5,11,12]$. 3D printed tracheas and tracheal splints are almost routinely saving newborns with serious breathing problems [13-15]. The $3 \mathrm{D}$ printers used for this work are not always expensive, high-end machines. Consumer-grade 3D printers and materials have been used for tracheal implants. Doctors at the Feinstein Institute for Medical Research used a MakerBot machine (about US \$2000) and ordinary PLA filament to 3D print custom scaffolding on which living cells were cultured for a tracheal implant [16]. MakerBot machines have also been used to 3D print patient-specific, biodegradable medicinal implants for treating bone infections and cancers [17].

The human heart is the subject of considerable 3D printing efforts. Aorta cells have been 3D printed at Sabanci University in Turkey [18]. The University of Louisville expects to 3D print a human heart by 2023 [19,20]. Kentucky-based Advanced Solutions intends to use its BioAssemblyBot printer to accomplish the feat [21]. In 2013, a California high schooler 3D printed a proof of concept customizable artificial heart [22]. And, to save existing hearts, Washington University in
John Hornick

Finnegan, Henderson, Farabow, Garrett \& Dunner, LLP, 901 New York Avenue, NW, Washington, DC 20001, USA john.hornick@finnegan.com 
St Louis is developing an elastic, 3D printed membrane that wraps around the heart like a glove. Its embedded sensors detect impending problems, and embedded electrodes deliver a life-saving shock when serious arrhythmias are detected [23].

Organovo, of San Diego, CA, USA, is 3D printing tissue used for drug testing and is working on a 3D printed human liver, which could eliminate animal testing of new drugs and enable safe and effective drugs to be brought to market much faster and at lower cost than they are today [24,25]. Others are working on $3 \mathrm{D}$ printable drugs, to be printed at home or where they are needed $[26,27]$.

Low-cost 3D printers are being used in war-torn developing countries, such as the Sudan and Uganda, to make prosthetics for amputees, of which there are 50,000 in the Sudan alone [28,29]. The US Army also wants to use $3 \mathrm{D}$ printing to counter some of the horrors of war. In a joint project with the University of Nevada, the army plans to $3 \mathrm{D}$ scan soldiers, from head to toe, and store the data in case the soldier loses a limb in

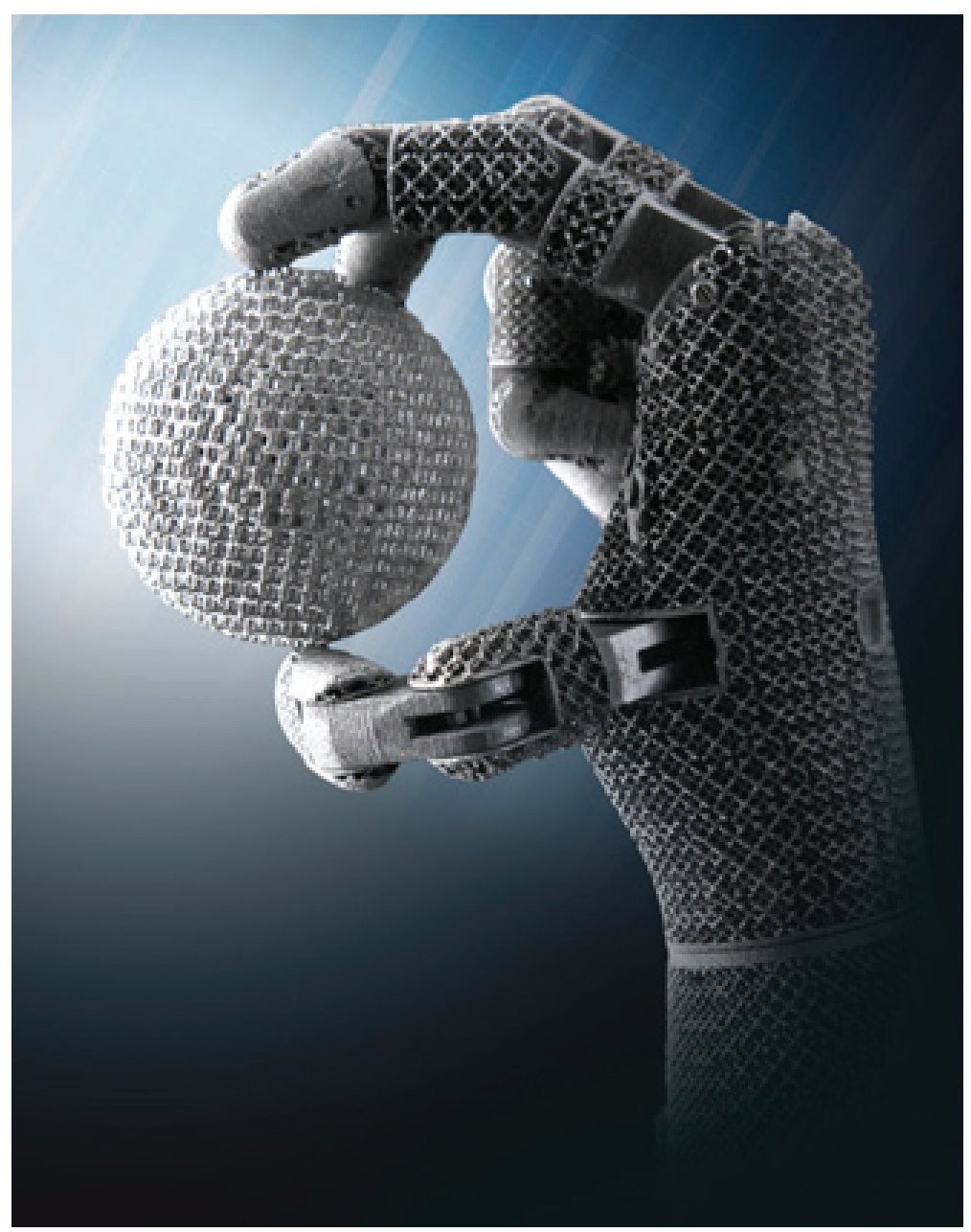

Figure 1. 3D printed hand.

Photo courtesy of Oak Ridge National Laboratory. combat. As Dr James Ma said [30]: "The idea is to image someone when they are in a healthy state so that the data is available if it's needed at a later point... We have soldiers who get injured. They lose limbs and other tissues and it's a challenge to reconstruct them in the field. But if they are imaged beforehand, you can send that over the internet and have a 3D printer in the field to produce the bone."

The Oak Ridge National Lab's award-winning, lightweight, low-cost 3D printed hand may be used in robotics, prosthetics, surgery and hazardous materials handling (Figure 1) [31]. A hydraulic pump powered by an electric motor located in the palm of the hand provides pressurized fluid to the finger joints, which cause gripping motion. An electric motor turns a cam that drives two master pistons each connected to five slave pistons, which cause the fingers to open or close. Since the fingers are hydraulically coupled, the digits will naturally conform to any device they grasp.

$3 \mathrm{D}$ printers have also been used to aid facial reconstructive surgery, with impressive results, including a full-face replacement in Belgium [32-34]. Researchers at Michigan Tech are using graphene and 3D printed scaffolds to rebuild damaged nerve tissue [35].

Italy's Del Bene Orthopedic Laboratory switched from traditional manufacturing to $3 \mathrm{D}$ printing for its human prosthetics and cut its production times by 75\%. Biomedical engineer Marco Avaro says [36]: "For a tibial prosthesis, I used to need eight hours. Now, I only need two." They have found that $3 \mathrm{D}$ printing prosthetics has other advantages. According to Avaro: "If we take the case of degenerative diseases, the geometries can become particularly difficult, very asymmetric, and the $3 D$ printer can reproduce exactly what we need."

A great medical application for $3 \mathrm{D}$ printing is surgical models and guides. Models of patient organs are being $3 \mathrm{D}$ printed and studied by surgeons before the first incision. Better to find anatomical anomalies and formulate strategy while studying models than while a patient lies on the operating table [37]. Surgeons at Miami Children's Hospital 3D printed a replica of a 4-year-old girl's heart to plan her complicated surgery [38]. Doctors at Boston's Children's Hospital practiced on a 3D printed model of a teenager's brain before operating on the real thing [39]. Texas Children's Hospital 3D printed the hearts, lungs, stomachs and kidneys of twins conjoined at the chest and abdomen so that surgeons could plan and practice their separation, which was a success [40]. Similarly, Chinese surgeons used a life-sized 3D printed model to practice separating conjoined twins who shared a single digestive tract. The model included many of the anatomical features they would encounter during surgery, such as bone joints and skin connections, which the surgeons practiced cutting to determine how best to separate the 
infants [41]. 3D printed models are also being used to train tomorrow's brain surgeons [42]. 3D printed surgical guides, such as guides customized for a patient's knee, enable surgeons to locate cuts precisely [43,44]. The printing of such guides is aided by software that turns 2D x-rays into 3D models [45]. Some hospitals are 3D printing surgical models and guides in-house. For example, Belgian 3D printing company Materialise opened a 3D printing center in Fuwai Hospital, China's largest cardio facility. According to the hospital, this collaboration will enable Fuwai to [46]: "..become China's leading center for $3 D$ printed heart model education, spreading knowledge of the technology and how it can be used by surgeons to the benefit of the Chinese public."

$3 \mathrm{D}$ printing is also being used for cosmetic surgery. A New York start-up, MirrorMe3D, 3D prints models showing what you will look like after cosmetic

\section{References}

13 D Printing and the Future of Manufacturing. Leading Edge Forum.12-13 (2012). https://assets1.csc.com/innovation/ downloads/LEF_20123DPrinting.pdf

2 Maxie K. Chinese Dr. Creates 3D Printed Skull Implant. Engineering.com (2013). www.engineering.com/3 DPrinting/3DPrintingArticles/ArticleID/6292/Chinese-DrCreates-3D printed-Skull-Implant.aspx

3 Gander K. 3D Printed Pelvis Helps Man with Rare Bone Cancer Keep Walking.Independent (UK). (2014). www. independent.co.uk/news/uk/home-news/3D printed-pelvishelps-man-with-rare-bone-cancer-keep-walking-9119473. html

4 Wohlers Report 2014. 3D Printing and Additive Manufacturing State of the Industry Annual Worldwide Progress Report Wohlers Associates, Fort Collins, CO, USA (2014).

5 Kuneinen E. Medical Application: 3D Printing a New Nose. 3D Printing Industry (2012). http://3dprintingindustry. com/2012/11/12/medical-application-3d-printing-a-newnose/

6 Molitch-Hou M. US Army's 3D Printed Skin Near Ready for Clinical Trials. 3D Printing Industry (2014). http://3dprintingindustry.com/2014/07/21/us-armys-3dprinted-skin-near-ready-clinical-trials

7 Heater B. Cornell Scientists 3D Print Ears with Help from Rat Tails and Cow Ears. Engadget (2013). www.engadget. com/2013/02/22/3d-printed-ear/

8 Maxie K. Artificial Human Ear Printed from Sheep Cells.Engineering.com (2013). www.engineering.com/3DPri nting/3DPrintingArticles/ArticleID/6116/Artificial-HumanEar-Printed-from-Sheep-Cells.aspx

9 Molitch-Hou M. The 'Six Million Dollar' Ear. (2013). http://3dprintingindustry.com/2013/05/06/the-six-milliondollar-ear $/$ ?utm_source $=3 \mathrm{D}+$ Printing + Industry + Updat e\&utm_medium $=$ email\&utm_campaign $=c d 0759105 c-$ RSS_EMAIL_CAMPAIGN\&utm_term=0_695d5c73dc- surgery [47]. Many Hollywood stars probably wish this company had existed before they went under the knife.

\section{Acknowledgements}

This article is an excerpt from the book 3D Printing Will Rock the World (available on Amazon or Kindle).

\section{Financial \& competing interests disclosure}

The author has no relevant affiliations or financial involvement with any organization or entity with a financial interest in or financial conflict with the subject matter or materials discussed in the manuscript. This includes employment, consultancies, honoraria, stock ownership or options, expert testimony, grants or patents received or pending, or royalties.

No writing assistance was utilized in the production of this manuscript.

\section{cd0759105c-60484669}

10 Park R. New Micro DSP 3D Printing Solution for the Hearing Aid Market. 3D Printing Industry (2012). http://3dprintingindustry.com/2012/10/27/new-micro-dsp3d-printing-solution-for-the-hearing-aid-market/

11 Pirroni R. Clear Correct Scales 3D Printed Digital Orthodontics Capacity by 30\%. 3D Printing Industry (2013). http://3dprintingindustry.com/2013/05/10/clearcorrectscales-3d-printed-digital-orthodontics-capacity-by-30/

12 Staff writer. Medical Success With 3D Printing. 3D Printing Insider http://3dprintinginsider.com/medical-success-with3D printing_b8184

13 Baby's Life Saved with Groundbreaking 3D Printed Device from University of Michigan that Restored his Breathing. Health System University of Michigan (2013). www. uofmhealth.org/news/archive/201305/baby\%E2\%80\%99slife-saved-groundbreaking-3d-printed-device

14 Stein R. Doctors Use 3D Printing to Help a Baby Breathe. NPR (2014). www.npr.org/sections/healthshots/2014/03/17/289042381/doctors-use-3-d-printing-tohelp-a-baby-breathe

15 Sher D. Can Organs Be 3D Bioprinted? A Stem Cell Trachea Will Tell. 3D Printing Industry (2014). http://3dprintingindustry.com/2014/02/06/can-organs3d-bioprinted-stem-cell-trachea-will-tell/?utm_source $=3 \mathrm{D}$ +Printing+Industry+Update\&utm_medium =email\&utm campaign $=66586 \mathrm{a} 01 \mathrm{ca}-\mathrm{RSS} \_$EMAIL_CAMPAIGN\&utm term $=0 \_695 \mathrm{~d} 5 \mathrm{c} 73 \mathrm{dc}-66586 \mathrm{a} 01 \mathrm{ca}-60484669$

16 Molitch-Hou M. Trachea 3D Printed with Ordinary MakerBot PLA.3D Printing Industry (2015). http://3dprintingindustry.com/2015/01/27/trachea-3dprinted-ordinary-makerbot-pla/

17 Sher D. Ordinary Replicator $2 X$ Used to 3D Print Bone Cancer Treatments. 3D Printing Industry (2015). http://3dprintingindustry.com/2015/02/03/amazing-3dprinting-app-uses-replicator-2x-cure-bone-infections-cancer/

18 Molitch-Hou M. Anatomically Accurate Aorta Cells 3D Printed at Sabancı University in Turkey. 3D Printing Industry 
(2014). http://3dprintingindustry.com/2014/03/20/3dprinting-aorta-cells-turkey/?utm_source $=3 \mathrm{D}+$ Printi ng+Industry+Update\&utm_medium =email\&utm campaign=d340f2a8af-RSS_EMAIL_CAMPAIGN\&utm _ term $=0 \_695 \mathrm{~d} 5 \mathrm{c} 73 \mathrm{dc}-\mathrm{d} 340 \mathrm{f} 2 \mathrm{a} 8 \mathrm{af}-60484669$

19 Krassenstein B. 3D Printed Human Heart By 2023. 3DPrint. com. (2014). https://3dprint.com/869/3d-printed-humanheart-by-2023-says-top-scientist/

20 Clark L. Bioengineer: The Heart Is One of the Easiest Organs to Bioprint, We'll Do It in a Decade. Wired UK (2013). www. wired.co.uk/news/archive/2013-11/21/3d-printed-wholeheart

21 Sher D. 3D Printed Organ Evolution Continues with BioAssemblyBot. 3D Printing Industry (2014). http://3dprintingindustry.com/2014/08/04/3d-printedorgan-evolution-continues-bioassemblybot/

22 A Custom Artificial Heart. Maker Faire (2013). http:// makerfaire.com/makers/a-custom-artificial-heart/

23 Halterman T. 3D Printing Used to Make Heart Problem Detector. 3D Printer World (2014). www.3dprinterworld. com/article/3d-printing-used-make-heart-problem-detector

24 Clark L. Bioengineers 3D Print Tiny Functioning Human Liver. Wired UK (2013). www.wired.co.uk/news/ archive/2013-04/24/3D printed-liver

25 Organovo. www.organovo.com

26 Kuneinen E. 3D Printing a Vaccine? 3D Printing Industry. (2012). http://3dprintingindustry.com/2012/11/20/3dprinting-a-vaccine/

27 You Will Be Able to 3D Print Customised Medicines on Demand within a Decade. 3ders.org (2014). www.3ders.org/ articles/20141102-you-will-be-able-to-3d-print-customisedmedicines-on-demand-within-a-decade.html

28 Heater B. Inexpensive 3D Limbs Could Bring New Hope to Sudan's 50,000 Amputees. Yahoo! Tech. (2014). www.yahoo. com/tech/inexpensive-3d-limbs-could-bring-new-hope-tosudans-75055744752.html

29 Grunewald S. Making Mass-Produced 3D Printed Prosthetics a Reality in Uganda. 3D Printing Industry (2014). http://3dprintingindustry.com/2014/01/21/making-massproduced-3d-printed-prosthetics-reality-uganda/

30 Krassenstein E. Military May Soon Be Able to Copy and 3D Print Exact Replicas of Bones and Limbs for Injured Soldiers. 3D print.com (2015). http://3dprint.com/44793/ copy-and-3d-print-bones/?utm_source $=$ Daily $+3 \mathrm{D}+$ Prin ting + News \&utm_campaign $=$ fbd 7 b 68 cle - Latest 3 3D Printing_News_02_17_2015_2_16_20158utm_ medium $=$ email\&utm_term $=0 \_861 \mathrm{dc} 04374$ fbd7b68c1e-226645849

$313 D$ Printed Lightweight Robotic Hand Wins 2012 R\&D 100. 3ders.org (2012) www.3ders.org/articles/20120809-3dprinted-lightweight-robotic-hand-wins-2012-RD-100.html

32 Kaelin B. A Look at How 3D Printing Made Belgium's First Full-Face Transplant Possible. 3D Printer World (2014). www.3dprinterworld.com/article/look-how-3d-printingmade-belgiums-first-full-face-transplant-possible

33 Chinese Man Who Lost Half of His Skull after Fall Will Have It Rebuilt with 3D Printed Mesh.3ders.org (2014). www.3ders. org/articles/20140828-chinese-man-who-lost-half-of-hisskull-after-fall-will-have-it-rebuilt-with-3d-printed-titaniummesh.html

34 Rogers P. How to Print a New Face. Forbes (2014). www. forbes.com/sites/paulrodgers/2014/03/13/how-to-print-anew-face/

35 Helsel S. Michigan Tech Integrating Graphene and 3D Printed Scaffolds to Rebuild Nerve Tissue. Inside 3D Printing. (2015). http://inside3dprinting.com/news/michigan-techintegrating-graphene-and-3d-printed-scaffolds-to-rebuildnerve-tissue/30455/

36 Sher D. DeltaWASP 3D Printer Quadruples Prosthesis Production for Orthopedic Lab. 3D Printing Industry (2015). http://3dprintingindustry.com/2015/02/04/ deltawasp-3d-printer-helps-italian-orthopedic-lab-quadrupleproduction $/$ ?utm_source $=3 \mathrm{D}+$ Printing + Industry + Updat e\&utm_medium=email\&utm_campaign=30e1dd966cRSS_EMAIL_CAMPAIGN\&utm_term $=0$ _695d5c73dc30e1dd966c-60484669

37 LaFrance A. To Help Solve Challenging Cardiac Problems, Doctors at Children's Press 'Print'.Washington Post (2013). www.washingtonpost.com/national/health-science/to-helpsolve-challenging-cardiac-problems-doctors-at-childrenspress-print/2013/05/13/b2eee214-8d9b-11e2-9838d62f083ba93f_story.html

38 Carreiro R. Doctors Use a 3D Printer to Help with Complicated Heart Surgery on a 4-Year-Old Girl. (2015). http://uproxx.com/technology/2015/01/doctors-use$3 \mathrm{~d}$-printer-to-help-with-complicated-heart-surgeryon -4 -year-old-girl/?utm_source $=$ Daily $+3 \mathrm{D}+$ Printin $\mathrm{g}+$ News\&utm_campaign $=95$ e1872531-Latest_3D_ Printing_News_01_21_2015_1_20_20158utm_ medium=email\&utm_term $=0 \_861 \mathrm{dc} 04374$ 95e1872531-226645849

39 McCluskey PD. 3D Printer Helps Doctors Prep for Complex Surgeries. Boston Globe (2015). www. bostonglobe.com/business/2015/01/18/with-printerdoctors-get-help-prepping-for-complex-surgeries/ Wf4GVpGMHapbG6sWGYlEYP/story.html?p1 = Article_ InThisSection_Bottom \&utm_source=Daily+3D+Prin ting + News\&utm_campaign $=$ e8ac90dd03-Latest_3D_ Printing_News_01_26_2015_1_25_2015\&utm_ medium $=$ email\&utm_term $=0 \_861 \mathrm{dc} 04374$ e8ac90dd03-226645849

40 Molitch-Hou M. Complex Separation of Conjoined Twins Successfully Planned with 3D Printing. 3D Printing Industry (2015). http://3dprintingindustry.com/2015/02/27/complexseparation-of-conjoined-twins-successfully-planned-with-3dprinting/

41 Chinese Doctors Use 3D Printed Replicas to Practice Separating Conjoined Twins. 3ders.org (2015). www.3ders.org/ articles/20150608-chinese-doctors-use-3d-printed-replicasto-practice-separating-conjoined-twins.html

42 Dhar M. Surgeons Practice on Brains Made on 3D Printers. HuffPost Healthy Living (2014). www.huffingtonpost. com/2013/11/20/surgeons-brains-3d-printerspractice_n_4309621.html

43 Park R. Materialise Acquires OrthoView and Its Orthopedic Digital Pre-Operative Planning Software. 3D Printing 
Industry (2014). http://3dprintingindustry.com/2014/10/21/ materialise-acquires-orthoview-orthopedic-digital-preoperative-planning-software/

Park R. 3D Printed Surgical Guides Make Their

Malaysian Debut. 3D Printing Industry (2013).

http://3dprintingindustry.com/2013/06/20/3d-printedsurgical-guides-make-their-malaysian-debut

45

Molitch-Hou M. Breakthrough Tech from Materialise Converts 2D X-Rays into 3D Prints. 3D Printing Industry (2014). http://3dprintingindustry.com/2014/09/22/breakthroughtech-materialise-converts-2d-x-rays-3d-prints/?utm_source $=3$
$\mathrm{D}+$ Printing + Industry + Update \&utm_medium $=$ email $\& u t m$ campaign=3e5a2583ab-RSS_EMAIL_CAMPAIGN\&utm_ term $=0 \_695 \mathrm{~d} 5 \mathrm{c} 73 \mathrm{dc}-3 \mathrm{e} 5 \mathrm{a} 2583 \mathrm{ab}-60484669 \mathrm{n}$

Molitch-Hou M. Materialise Helps to Open 3D Printing Center in Beijing Hospital. 3D Printing Industry (2015). http://3dprintingindustry.com/2015/06/24/materialiseopens-3d-printing-center-in-beijing-hospital

47 Murphy M. See What You'll Look Like after Plastic Surgery with a 3D printed Bust of Your Head. Quartz (2015). http:// qz.com/427157/see-what-youll-look-like-after-plasticsurgery-with-a-3D printed-bust-of-your-head 
